\title{
Redesign Presentation Technique: Challenges to Encourage Learning Motivation
}

\author{
$1^{\text {st }}$ Agus Purnomo \\ Social Studies Program \\ Universitas Negeri Malang \\ Malang, Indonesia \\ agus.purnomo.fis@um.ac.id \\ $2^{\text {nd }}$ Bayu Kurniawan \\ Social Studies Program \\ Universitas Negeri Malang \\ Malang, Indonesia \\ bayu.kurniawan.fis@um.ac.id
}

\author{
$3^{\text {rd }}$ Saiful Amin \\ Department of Social Studies \\ UIN Maulana Malik Ibrahim Malang \\ Malang, Indonesia \\ amin.geo87@pips.uin-malang.ac.id \\ $4^{\text {th }}$ Nevy Farista Aristin \\ Department of Geography Education \\ Universitas Lambung Mangkurat \\ Banjarmasin, Indonesia \\ nevyfarista@ulm.ac.id
}

\begin{abstract}
Communicating is one of the demands of scientific learning that requires students to explain to their learning partners about what they have already obtained (learning outcomes). Design to communicate this through performance or class presentations in groups or independently. The main goal is to facilitate the learning character of students who are more receptive to explanations from their peers than from their facilitators. However, the findings in the classroom as much as $80 \%$ of students do not prepare for a discussion of the findings of his study; they feel already completed the obligations it when it is communicating the results in the classroom. Lottery Presentation Design is a modification of regular presentations made in groups, namely by drawing three groups (consisting of 3-4 students) who will present on the same day, and divide the things presented into several sections. After completing the draw, the lottery number is put back into the lottery, which means that the group that has advanced makes it possible to return to the next meeting to present the part that has not. Motivation to learn indicated by the participant students. Learning motivation data includes: (1) Before implementation which measured from the desire to prepare themselves and (2) when learning measure from (a) the desire to be involved from the beginning of learning, (b) the duration of involvement, and (c) the type of involvement. Collection using a questionnaire and observation. Existing data were analyzed descriptively using a single tabulation to determine learning motivation patterns.
\end{abstract}

\section{Keywords: redesign, presentations, learning motivation}

\section{INTRODUCTION}

Communicating is the ability to deduce facts that have observed. In scientific learning, there stages that require students to explain to their learning partners about what they have gained (learning outcomes) [1]. The purpose of communicating is to develop the science studied so that the scientific study is not single. However, in reality, students feel that communicating in the form of a presentation in front of the class is only to abort their obligations $[2,3,4]$. The impact is that many of them are not serious about preparing for presentations. This weakness is an accumulation of environmental factors such as institutions, lecture, and learning environments [5].

The findings suggest that as many as $80 \%$ of students do not prepare for a discussion of the findings learn his [6]. They felt it fall obligation when it is communicating the results in the classroom although there are some of those who feel more comfortable and more accessible to absorb information comes from his friend (peer tutor) so that the variation of learning by the presentation is a form of diversifying efforts to learn students. Because, basically, respectively - each of them has its way of learning [7].

One way is to increase their learning motivation through a challenging presentation design so that they are more severe in preparing. The design is in the form of a draw the order of presentation; the canary is as follows.

1. Students give time to collect data and arrange their scientific work within a specific time (within ten days)

2. A week before the presentation they have explained the rules of the presentation, namely;

a. Presentation time agreement (in this case the presentation was agreed in a span of 3 weeks because 
the group that has made a presentation will have the opportunity to make a presentation again with a discussion that has not presented

3. The facilitator has the authority to annul the presentations that considered inadequate, namely :

a. There is no novelty aspect

b. The presentation is only in the form of theoretical insight without being accompanied by examples/facts

c. The material used is not optimal

The purpose of this rule is that they prepare themselves optimally
Collecting data from internet source (between 10 days)

\section{Explanation of the main} rules in presentation

a. Before presentation every single group have responsibility to upload paper in e-learning

b. Each presentation have 20 minutes to describe main topic

c. Lecture have authority to control presentation

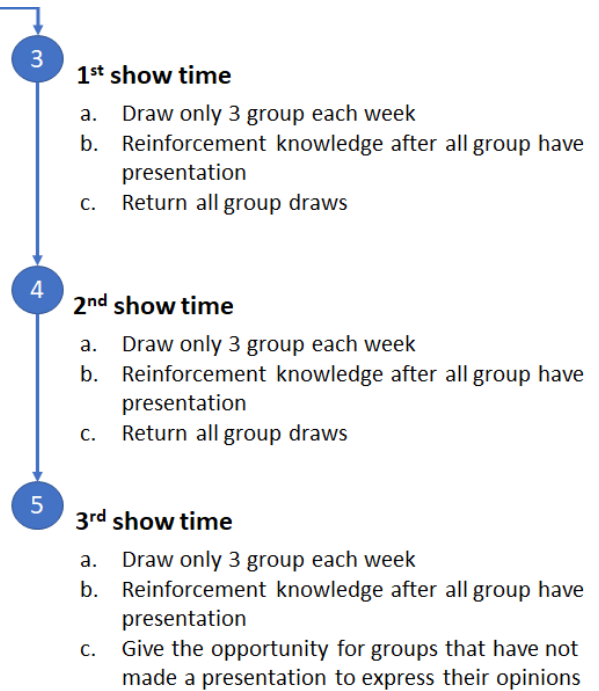

Fig. 1. Redesign Presentation Model

The papers that have collected will be uploaded to the elearning account so that they accessed by all students; the goal is to make the discussion process more dynamic.

The design is expected to be able to increase the willingness of students to prepare themselves to participate in learning (Error! Reference source not found.). In the learning activities observational motivation includes; (1) Before the implementation measured from the desire to prepare themselves and (2) when learning measured from (a) the desire to be involved from the beginning of the learning, (b) the duration of involvement, and (c) the type of involvement. Collection using a questionnaire and observation.

\section{METHOD}

The design used in discussing these findings is descriptive in one homogeneous group analyzed using a single tabulation. This design is appropriate to explain the gaps that result from the treatment that subjects get $[8,9]$. The subject of observation was the 2016 class of regional geography courses consisting of 2 classes. There was no difference in treatment between the two classes. The purpose of the same treatment is to observe the patterns in each student's character. For the collection of data using techniques, observe using observation sheet instruments (Error! Reference source not found.) and assisted by at least.

TABLE I. OBSERVATION FORM

\begin{tabular}{|c|c|c|c|c|c|c|c|}
\hline \multirow{2}{*}{ Subject } & \multicolumn{3}{|c|}{$\begin{array}{c}\text { Willingness to } \\
\text { involve }\end{array}$} & \multirow{2}{*}{$\begin{array}{l}\text { Involve } \\
\text { form* }\end{array}$} & \multicolumn{3}{|c|}{$\begin{array}{l}\text { Willingness to } \\
\text { maintain focus }\end{array}$} \\
\hline & $\begin{array}{c}0-5 \\
\mathrm{~m}\end{array}$ & $\begin{array}{c}5-10 \\
\mathrm{~m}\end{array}$ & $\begin{array}{l}>10 \\
\mathbf{m}^{*}\end{array}$ & & $\begin{array}{c}0-5 \\
\mathrm{~m}\end{array}$ & $\begin{array}{c}5-10 \\
\mathrm{~m}\end{array}$ & $\begin{array}{c}>10 \\
\mathbf{m}\end{array}$ \\
\hline \multicolumn{8}{|l|}{$\mathrm{A}$} \\
\hline \multicolumn{8}{|l|}{ Note } \\
\hline \multicolumn{8}{|l|}{$\mathrm{B}$} \\
\hline Note & & & & & & & \\
\hline
\end{tabular}

: forms of involvement such as reading, taking notes, interpreting, discussing, asking questions, listening, and give opinions. That can observe in student learning activities 


\section{RESULTS AND DISCUSSION}

The results of treatment for three lectures prove that students learn in their way. At the first meeting they were still looking for patterns and felt challenged by new patterns. Because the results of the first lectures, there two groups that disallowed because they were considered less than optimal in the presentation, then their second meeting was increasingly challenged to prove that they could meet the intended criteria. However, at the third lecture, those who seemed to have found and recognized the patterns felt bored and decreased their motivation (Error! Reference source not found.).

From the above results it is concluded that there is a level at which students are no longer likely to get the same treatment. As can be seen from the meeting three which shows the willingness of students to be involved from the beginning and survive decreased compared to the previous meeting. However, the results of the lottery presentation treatment showed that it was able to increase the maximum motivation to study for two meetings.

This condition refers to their learning motivation. Basically motivation has been defined as "an internal state that activates, guides, and maintains behavior" [10]. From an educational point of view, motivation can apply to any process that triggers or maintains learning focus. Most recent research has adopted a social cognitive view [11]. In contrast to the old model in which motivation is assumed to be a relatively stable personality trait, social cognitive views have a belief that motivation can be significantly influenced by aspects of the classroom context [12]

Motivation has described in the form of extrinsic and intrinsic. Intrinsic motivation refers to the tendency to do something because of interest or pleasure, and extrinsic motivation refers to the tendency to do something because it has separated results [13]. Therefore extrinsic motivation focuses on individual external factors and tasks, such as appreciation, praise, privilege, or attention $[14,15,16]$. For example, the teacher can give students praise for work that has already been completed right. On the other hand, intrinsic motivation directly related to the task performed. According to intrinsic motivation theory, one feels happy when learning something new or succeeding in a challenging task. That creates a feeling of confidence and mastery that strengthens oneself, so students will be more inclined to engage in learning activities in the future. Intrinsic motivation is generally considered to be more effective in promoting learning and achievement [13].

Motivation Intrinsic can improved in the classroom by providing challenge, curiosity, fantasy, and control [17]. Challenge refers to the level of difficulty that will enable students to experience a sense of mastery and competence when they succeed. The level of challenges presented can vary in the form of assignments from students to students according to their abilities, but this difference can be compensated to enable them to work at their own pace sometimes, or who finishes early [18]. Intrinsic motivation can also increase if activities utilize imagination and fantasy because this allows them to step out of real-life and make comparisons with real life.
Assignments can also increase learning motivation. With notes, class assignments must be meaningful and relevant to students' lives, so that there are perceived benefits in understanding content [19]. So that at the end of the learning they get regular feedback on the assessment tasks, and praise must be given for improvements in mastering new work, not just for high performance [20]. Comparison of social outcomes and feedback should avoid, and preferably, there should be a recognition of their efforts [21].

The expectation value is related to students' assessment of their expectations of the success and usefulness of the content [22]. Expectations are students' beliefs about their abilities and opportunities for success in carrying out their specific tasks, while the value of the assignment refers to the perceived value of the material to learn. Three types of values have identified. "Top Value" is the extent to which tasks relate to self-image. For example, students who consider themselves talented in the field of social studies want to confirm by studying social studies well. " Utility value " concerns the usefulness of the task. For example, studying social studies can help to enter a social science program at a university. "Intrinsic Value" refers to the enjoyment inherent in the task, and is very closely related to the construction of intrinsic motivation.

If motivation is a prerequisite for knowledge development, educators should try to promote as much positive motivation as possible and to do this; they should ideally utilize various motivational strategies. The following is a summary of strategies for the construction of motivation [11] explained in the previous section.

In order to increase student motivation, educators must:

1. Challenge students by assigning tasks at stages of difficulty that range from very easy to very difficult;

2. Use students' personal experiences to arouse curiosity;

3. Using fantasy/imagination as a strategy to stimulate students' thinking power beyond current conditions;

4. Increasing the meaningfulness of content and tasks by relating them to everyday life;

5. Use various types of activities and tasks;

6. Involve students to become active participants in learning;

7. Allows students to choose their co-workers, activities and task formats independently to create a democratic atmosphere;

8. Enabling students to work individually or together in situations that do not encourage competition, the aim is for mutual learning ;

9. Provide assessment feedback, and use praise that rewards effort and improvement (this must be given in person, to avoid social comparison);

10. Supporting, convincing, and attentive to students.

Of course, some students still motivated even if the educator does not utilize this strategy. They may already have high 
individual interests or well-developed learning goals. However, research shows that, during high school and college, there were very few of them. That is generally a steady decrease in motivation during middle school [23], especially in the social sciences [24, 25]. That also happens because the learning load is too much after they spend a day of energy and attention in class. They still have to do additional assignments which sometimes forget the essence of associating content with their daily lives. Our curriculum emphasizes knowing a little about many things than knowing a lot about a few things. That means that students cannot focus on one area of interest. Despite that fact, it can conclude that there various motivational strategies that can integrate into the classroom.

\section{CONCLUSION}

The lottery presentation model is proven to increase students' learning motivation in regional geography courses. However, its application is limited to only two treatments because they will feel bored getting the same treatment. That proves that this model can provide challenges so that it can increase learning motivation.

\section{REFERENCES}

[1] Zaim, "Implementing Scientific Approach to Teach English at Senior High School in Indonesia," Asian Social Science, vol. 13, no. 2, pp. 33 40, 2017.

[2] S. Živković, "The Importance Of Oral Presentations For University Students," Mediterranean Journal of Social Sciences, vol. 5, no. 19, pp 468-475, 2014.

[3] R. J. Craig and J. H. Amernic, "PowerPoint Presentation Technology and the Dynamics of Teaching," Innovative Higher Education, vol. 31, no. 3, pp. 147-160, 2006.

[4] S. Aloraini, "The impact of using multimedia on students' academic achievement in the College of Education at King Saud University," Journal of King Saud University - Languages and Translation, vol. 24, no. 2, pp. 75-82, 2012.

[5] S. Hussain, Z. F. Muhsin, Y. K. Salal, P. Theodorou, F. Kurtoğlu and G. Hazarika, "Prediction Model on Student Performance based on Internal Assessment using Deep Learning," International Journal of Emerging Technologies in Learning, vol. 14, no. 8, pp. 4-22, 2019.

[6] A. Purnomo, "LESSON STUDY (Kolaborasi untuk Memfasilitasi Motivasi Belajar Peserta Didik dan Meningkatkan Kualitas Pembelajaran)," Universitas Negeri Malang, Malang, 2016.

[7] H. Gardner, Multiple Intelligences: New Horizons in Theory and Practice, New York: Basic Books, 2006.

[8] F. Alqraini, "Single-Case Experimental Research: A Methodology for Establishing Evidence-Based Practice in Special Education,"
International journal of special education, vol. 32, no. 3, pp. 551-566, 2017.

[9] D. R. Spurlock, "The Single-Group, Pre- and Posttest Design in Nursing Education Research: It's Time to Move on," Journal of Nursing Education, vol. 57, no. 2, pp. 69-71, 2018.

[10] Green, "Using an expectancy-value approach to examine teachers' motivational strategies," Teaching and Teacher Education, vol. 18, no. 8, p. 989-1005, 2002.

[11] A. Purnomo and B. Kurniawan, "Motivation to Learn Independently through Blended Learning," in 6th International Conference on Educational Research and Innovation (ICERI 2018), Yogyakarta, 2019.

[12] Pintrich and Schunk, Motivation in education: Theory, research and applications, Englewood Cliffs: Prentice Hall, 1996.

[13] Deci, Koestner and Ryan, "Extrinsic rewards and intrinsic motivation in education: Reconsidered once again," Review of Educational Research, vol. 71, no. 1, pp. 1-27, 2001.

[14] Bagon and L. Vodopivec, "Motivation for Using ICT and Pupils with Learning Difficulties," International Journal of Emerging Technologies in Learning, vol. 11, no. 10, pp. 70-75, 2016.

[15] S. Wichadee, "A Development of the Blended Learning Model Using Edmodo for Maximizing Students' Oral Proficiency and Motivation," International Journal of Emerging Technologies in Learning, vol. 12, no. 2, pp. 137-154, 2017.

[16] M. Li and Y. Ren, "A Multimedia Teaching Model for "Sports Statistics" Based on ARCS Motivation Theory," International Journal of Emerging Technologies in Learning, vol. 13, no. 9, pp. 15-28, 2018.

[17] Lepper and Hodell, "Intrinsic motivation in the classroom," in Research on motivation in education, vol. 3, C. A. \&. R. Ames, Ed., San Diego, Academic Press, 1989, pp. 73-105.

[18] Stipek, Motivation to learn: Integrating theory and practice, 4th ed., Boston: MA: Allyn and Bacon, 2002.

[19] C. Ames, "Classrooms: Goals, structures, and student motivation," Journal of Educational Psychology, vol. 84, no. 3, pp. 261-271, 1992.

[20] Xiang, McBride and Solmon, "Motivational climates in ten teachers' elementary physical education classes: An achievement goal theory approach," The Elementary School Journal, vol. 101, no. 1, pp. 71-93, 2003.

[21] S. Deemer, "Classroom goal orientation in high school classrooms: Revealing links between teacher beliefs and classroom environments," Educational Research, vol. 46, no. 1, pp. 73-90, 2004.

[22] Wigfield and Eccles, "Expectancy-value theory of achievement motivation," Contemporary Educational Psychology, vol. 25, no. 1, pp 68-81, 2000.

[23] Anderman and Maehr, "Motivation and schooling in the middle grades," Review of Educational Research, vol. 64, no. 2, pp. 287-309, 1994

[24] Butler, "Factors associated with students' intentions to engage in science learning activities," Journal of Research in Science Teaching, vol. 36, no. 4, pp. 455-473, 1999.

[25] Tobin, Tippins and Gallard, "Research on instructional strategies for teaching science," in Handbook of research on science teaching and learning, Gabel, Ed., New York, Macmillan, 1994, pp. 45-93. 